THE TERRORIST ALBUM 



\title{
The Terrorist Album
}

Apartheid's Insurgents, Collaborators, and the Security Police

\author{
JACOB DLAMINI
}

\author{
III \\ III \\ Harvard University Press \\ Cambridge, Massachusetts \\ London, England \\ 2020
}


Copyright (C) 2020 by the President and Fellows of Harvard College All rights reserved Printed in South Africa, 2020

$$
\begin{gathered}
\text { First printing } \\
\text { Jacket design: Tim Jones } \\
9780674245532 \text { (EPUB) } \\
9780674245563 \text { (MOBI) } \\
9780674245587 \text { (PDF) }
\end{gathered}
$$

The Library of Congress has cataloged the printed edition as follows:

Names: Dlamini, Jacob, 1973- author.

Title: The terrorist album : apartheid's insurgents, collaborators, and the security

$$
\text { police / Jacob Dlamini. }
$$

Description: Cambridge, Massachusetts : Harvard University Press, 2020. | Includes bibliographical references and index.

Identifiers: LCCN 2019049259 | ISBN 9780674916555 (cloth) | ISBN 978-0-674-24870-0 (South African edition)

Subjects: LCSH: Anti-apartheid movements—South Africa. | Anti-apartheid activists—South Africa. | Apartheid—South Africa. | Police—South Africa. | Post-apartheid era-South Africa.

Classification: LCC DTi757 .D585 2020 | DDC 305.800968-dc23

LC record available at https:/ / lccn.loc.gov/ 2019049259 
For Simanga Tsotetsi and Khaya Lynn 

Who are you who will read these words and study these photographs, and through what cause, by what chance, and for what purpose, and by what right do you qualify to, and what will you do about it?

- James agee, Let Us Now Praise Famous Men

If I open my old photo albums, my companions from the past, most of them dead now, look back at me. Some days it gives a sad kind of pleasure, and then other days, the same activity brings me face to face with nothingness. So many of the men, the women, were young and charming, truly beautiful. They will never be old. Soon it becomes intolerable to realize that they're in a tomb or reduced to ashes. I close the album.

When I look at those photos from the past, I have the impression that the present is a foreign country. I live here in exile. 
